\title{
Non-lethal age determination for juvenile goliath grouper Epinephelus itajara from southwest Florida
}

\author{
John H. Brusher ${ }^{1, *}$, Jennifer Schull ${ }^{2}$ \\ ${ }^{1}$ NOAA Fisheries, Southeast Fisheries Science Center, 3500 Delwood Beach Road, Panama City, Florida 32408, USA \\ ${ }^{2}$ NOAA Fisheries, Southeast Fisheries Science Center, 75 Virginia Beach Drive, Miami, Florida 33149, USA
}

\begin{abstract}
Previous studies have developed size-at-age curves for goliath grouper; however, these data were based on relatively few immature individuals, and age estimation was otolith-based, requiring sacrifice of this federally protected fish. In the present study, scales, dorsal fin-rays and dorsal spines were explored as potential non-lethal ageing alternatives for juvenile goliath grouper. Annulus marks were validated using marked-recaptured fish, oxytetracycline injections, and edge analysis. A subset of fish was sacrificed to compare the scale, spine and ray ages to otolith ages. A $40 \%$ recapture rate provided a useful time series of in situ age and growth data. Scale and ray ages were unreliable, but dorsal spines demonstrated agreement with corresponding otolith ages. Annuli were best represented by translucent bands in spines, as opposed to opaque bands in otoliths. Spines were positively validated for periodicity of annulus formation. Annuli formed at different times of the year in spines than in otoliths. By correcting for this difference using a biological age method, better agreement between otolith and spine age was achieved. Dorsal spines are recommended as the primary method for ageing goliath grouper between the ages of 0 and 6 yr. This study illustrates the use of a non-lethal method to determine age of a protected species.
\end{abstract}

KEY WORDS: Epinephelidae - Epinephelus itajara · Goliath grouper · Jewfish · Protected species · Age and growth $\cdot$ Dorsal spines $\cdot$ Dorsal fin-rays $\cdot$ Otoliths $\cdot$ Age validation $\cdot$ Non-lethal ageing

\section{INTRODUCTION}

Goliath grouper Epinephelus itajara is the largest epinephalid species in the western North Atlantic, attaining sizes of $250 \mathrm{~cm}$ total length (TL) and $320 \mathrm{~kg}$ total weight, and living for at least $37 \mathrm{yr}$ (Sadovy \& Eklund 1999). It is an apex predator and aggregation spawner that is slow growing and late to mature. These life history characteristics and its suitability as a food fish make the species highly susceptible to fishing pressure (Huntsman et al. 1999). As a result of declining abundance, goliath grouper has been protected from all take in US waters since 1990 (in the US Caribbean, since 1993) and was listed as a 'species of concern' under the Endangered Species Act (ESA) until 2006. Furthermore, it is considered 'conservation dependent' by the American Fisheries Society (Musick et al. 2000), and included on the International Union for the Conservation of Nature (IUCN) Red List of threatened animals (Hudson \& Mace 1996).

Post-larval and juvenile goliath grouper recruit to estuaries. The historical center of abundance for juvenile goliath grouper in US waters is the Ten Thousand Islands area of southwest Florida, USA (Bullock \& Smith 1991, Bullock et al. 1992). Goliath grouper in this area are generically characterized as sexually immature fish from settlement to approximately $1000 \mathrm{~mm}$ TL and approximately 6 yr of age (Bullock et al. 1992, Koenig et al. 2007). Generally, juvenile goliath grouper show high site fidelity moving little within their home range environment (Eklund \& Schull 2001, Koenig et al. 2007). Upon reaching sexual maturity (1100 to $1350 \mathrm{~mm}$ TL), individuals move offshore from this habitat as part of an ontogenetic migration. 
Traditionally, otoliths have been the most reliable hard part for age determination and validation in teleost fishes (Beamish \& McFarlane 1983, Jearld 1983, Lowerre-Barbieri et al. 1994, Ihde \& Chittenden 2002), even proving useful for ageing tropical and subtropical species that experience small variation in water temperature (Manooch 1987). A goliath grouper age and growth study was conducted by Bullock et al. (1992) which entailed sampling specimens from both recreational and commercial landings and using sagittal otoliths for age determination. Of the 384 individuals that Bullock et al. (1992) aged, only about 50 were juveniles (i.e. sexually immature, $<1000 \mathrm{~mm}, \leq 6 \mathrm{yr}$ old). Bullock et al. (1992) counted the opaque bands as annuli on the sectioned otoliths and used intramuscular injections of oxytetracycline (OTC) to determine the validity of the age marks. However, otoliths can only be obtained by killing fish, which is clearly undesirable for protected species (Jearld 1983, Welch et al. 1993). Because the goliath grouper is currently protected, there was a need to determine whether other hard parts available for non-lethal removal, such as soft dorsal fin-rays (rays), scales, or rigid dorsal spines (spines), could be used instead. The use of hard parts other than otoliths for age determination is well documented for many different species (Beamish \& McFarlane 1985, Welch et al. 1993, Franks et al. 2000, Ihde \& Chittenden 2002, G. W. Ingram et al. pers. comm.).

The objectives of the present study were to (1) determine if spines, rays, or scales, rather than otoliths, could be used to age juvenile goliath grouper; (2) validate these ageing structures using mark-recapture, OTC validation and hard part edge analysis; and (3) compare our results to previous age and growth studies. Achieving these objectives will better describe the population structure of juvenile goliath grouper. To our knowledge, this is the first study to use non-lethal methods to estimate age of an epinepheline grouper.

\section{MATERIALS AND METHODS}

Sample collection. A total of 1683 juvenile goliath grouper were captured and released from 1997 through 2003 as part of juvenile goliath grouper density and abundance study in the Ten Thousand Islands area of southwest Florida, USA (Koenig et al. 2007) (Fig. 1). Following the methods described in Koenig et al. (2007), trotlines, blue crab traps and fish traps were used to capture goliath grouper during the summer and fall when catch rates were typically highest; however juveniles were also opportunistically sampled during other times of year.

At first capture, fish were weighed, measured, and tagged with a Floy internal steel-core, numbered anchor tag. The third dorsal spine and second and third dorsal rays were removed using wire clippers and a scalpel. Following G. W. Ingram et al. (pers. comm.) and Ihde \& Chittenden (2002), the shaft of each spine or ray was cut 5 to $10 \mathrm{~mm}$ above the condyle or base of the spine. Ray and spine samples from recaptured fish were taken from rays and spines adjacent and posterior to ones that had previously been removed. Three scale samples (5 to 6 individual scales) were taken from the left side of each fish dorsally above the lateral line (dorsal), ventrally behind the pectoral fin (belly), and anterior to the caudal peduncle (tail) as described by Jearld (1983). Hard part samples were not collected from fish that were recaptured within 6 mo of a previous capture to allow adequate time for growth. All fish were released quickly (generally within $15 \mathrm{~min}$ ) at their capture location. A subset of fish $(n=35)$ was sacrificed in order to compare otolith-based age estimates to spine, ray, and scale-based estimates.

Mark-recapture of chemically-tagged (OTC) fish is one of the best methods available for validating the periodicity of growth increment formation (Campana, 2001). Therefore, a subset of marked fish $(n=152)$ was injected intramuscularly with OTC (Maxim, $200 \mathrm{mg}$ $\mathrm{ml}^{-1}$ ) to validate annulus formation (Beamish \& McFarlane 1983, Bullock et al. 1992, Campana 2001). Initial doses of OTC administered in 1997 through mid-1999 varied from 6 to $426 \mathrm{mg} \mathrm{kg}^{-1}$ body weight; a standard dose of $50 \mathrm{mg} \mathrm{kg}{ }^{-1}$ was thereafter adopted following recommendations in the literature (Bullock et al. 1992, McFarlane \& Beamish 1987, Fowler \& Short 1998).

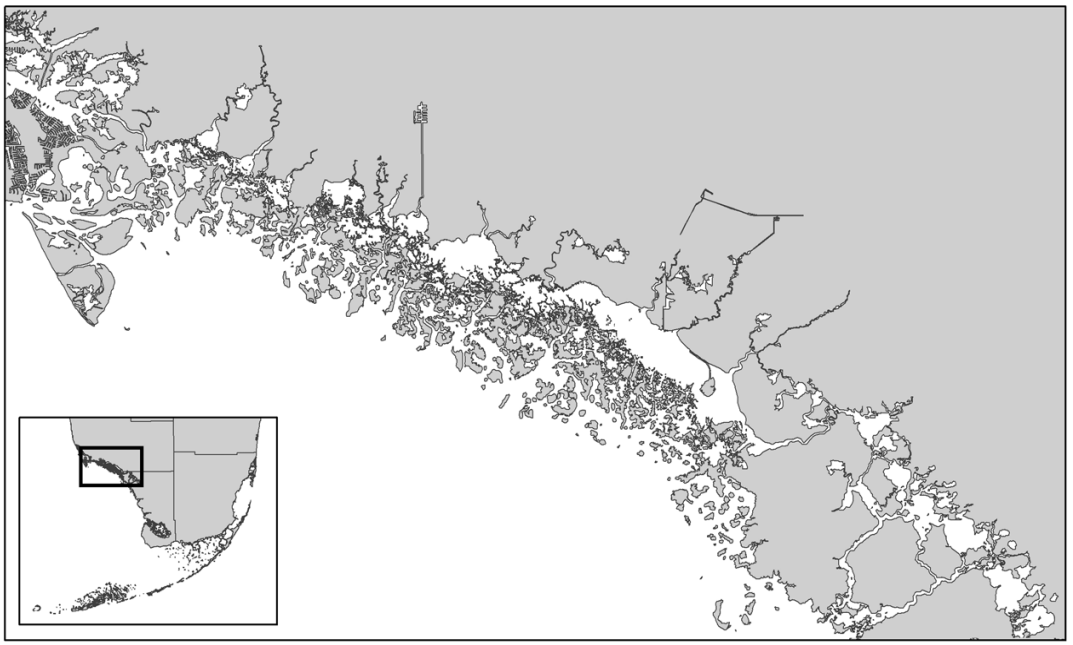

Fig. 1. Study region $\left(26^{\circ} 00.20^{\prime} \mathrm{N}, 81^{\circ} 43.50^{\prime} \mathrm{W}\right.$ to $\left.25^{\circ} 41.50^{\prime} \mathrm{N}, 81^{\circ} 15.00^{\prime} \mathrm{W}\right)$, the Ten Thousand Islands region of southwest Florida, USA 
Sample preparation. Spine and ray samples were frozen until processed, and then thawed, dried in a drying oven $\left(60^{\circ} \mathrm{C}\right)$ or in a cool dark location, manually cleaned of excess tissue, and stored dry. Samples were then sectioned with a Buehler Isomet low-speed saw. Three serial transverse sections $0.5 \mathrm{~mm}$ thick were cut from the base of each spine or ray. Sections were air dried and then mounted to microscope slides using Lerner Laboratories Pro-Texx mounting media.

Sagittal otoliths were cleaned and stored dry and subsequently imbedded in epoxy and sectioned using a Beuhler Isomet low-speed saw. Three serial transverse sections $0.5 \mathrm{~mm}$ thick were cut to ensure that the core and first band would be visible. Sections were then fixed to microscope slides using Lerner Laboratories Pro-Texx mounting media.

Collected scales were cleaned using freshwater, and stored dry. Scales were pressed between 2 glass plates and read on a standard microfiche reader as per Jearld (1983).

Interpretation of bands. Spine and ray sections were examined for age marks using a dissecting microscope illuminated from below. An attached camera displayed the image of the sample on a computer monitor. Translucent bands in sectioned spines and rays were counted as annuli. Otoliths were read according to the methods of Secor et al. (1992) using a compound microscope at 40× magnification and reflected light. Opaque bands were counted as annuli for otoliths. Typically, marine fishes off the southeastern US complete annulus formation (opaque zone) by late spring to early summer (Patterson et al. 2001, Wilson \& Nieland 2001, Smith \& Deguara 2003, Garcia et al. 2003). The opaque zone is the thinnest and most distinctive zone in the otolith as the fish ages, whereas, for spines and rays, the translucent zone is the thinnest and most distinctive. Previous studies supported use of translucent zones as annuli (Welch et al. 1993, Franks et al. 2000, Ihde \& Chittenden 2002, G. W. Ingram et al. pers. comm.). For scales, opaque bands (thinnest and most distinctive) were counted as annuli as per Jearld (1983).

For otoliths, spines, and rays, 2 readers independently aged each sample. If counts did not agree, the sample was viewed again with both readers present and eliminated if agreement could not be reached. Two readers independently examined scales from each fish, ageing scales from 3 locations on the fish's body for 6 readings per fish. The mode of the 6 readings was used as the age estimate. Researchers also recorded percent agreement between scales taken from the 3 distinct areas on the fish to determine if scales from a certain region were more reliable than others. We compared regression equations for annulus counts on each hard part versus otolith age.
Validation techniques. Edge analysis was conducted for all aged fish to determine the time period of annulus formation (Campana 2001). For each month of capture, the percent of samples with an annulus on the distal edge of the section was computed. Marginal increment analysis, which had been employed by Bullock et al. (1992) to validate period of annulus formation, was bypassed in favor of edge analysis which qualitatively describes the character of the edge of the hard part. Marginal increment analysis can be subjective and misused in age and growth studies (Campana 2001).

Because approximately $40 \%$ of our tagged fish were recaptured, we were able to follow the changes in their hard parts as they grew in situ. We examined the spines of juvenile goliath grouper that had been recaptured after at least $1 \mathrm{yr}$ at large to determine if age increased proportionally to known time at large. Additionally, hard parts from recaptured fish that had been previously injected with OTC were used to determine if there was a consistent, annular pattern of growth past the OTC mark. This was done by recording the number of annuli and/or growth distal to the OTC mark in the marked-recaptured fish and comparing this to the previous age determination given to the fish at the time of capture and injection.

Assignment of age. Ages were assigned based upon timing of annulus completion and edge interpretation (Patterson et al. 2001, Wilson \& Nieland 2001, Smith \& Deguara 2003, Garcia et al. 2003). This timing of otolith zone formation was established for goliath grouper by Bullock et al. (1992). For example, an otolith with a large translucent zone early in the year would be expected to complete an opaque annulus by late spring to summer. Therefore, age equals otolith opaque counts plus 1 yr until approximately August for fish with translucent margins. After this date, age equals opaque zone count. Spine age was also re-calculated based on timing of translucent zone (annulus) formation.

Edge analysis indicated that spines and rays deposited annuli at different times of the year than did otoliths, and that the timing of the first annulus mark in the structures was also dissimilar. In spines and rays, the first annulus (translucent) is deposited by December, which is 4 mo after an assumed hatching date of September 1 (Bullock et al. 1992). In the corresponding otoliths, the first annulus (opaque) is deposited by August (Bullock et al. 1992). Therefore, biological ages were calculated for each hard part by adding or subtracting fractions of years (days) from the total number of annuli, based on date of capture (Jearld 1983, Lowerre-Barbieri et al. 1994, G. W. Ingram et al. pers. comm.), allowing for the subtraction of the number of days from the inferred September 1 hatching date (Bullock et al. 1992) to the first annulus deposit.

Age and growth. Once corrected, the method described above was applied to all spines aged dur- 
ing this study $(\mathrm{n}=1114)$. These ages and corresponding lengths were then compared to the von Bertalanffy growth model for goliath grouper in the eastern Gulf of Mexico published by Bullock et al. (1992) as a comparison of the only 2 ageing studies for goliath grouper.

\section{RESULTS}

\section{Sample collection}

Hard parts were collected from fish caught between 1997 and 2001 ( $\mathrm{n}=1144)$. A total of 667 fish were recaptured, with 275 recaptured 2 or more times, for a total of 1913 capture events. We collected 1207 spine samples, 844 ray samples, 903 scale sets, and 35 otoliths. Fish ranged in size from 145 to $1005 \mathrm{~mm}$ TL (mean $\pm \mathrm{SD}=419 \pm 165 \mathrm{~mm}$ ). From initial investigation, readers had low confidence in both ray and scale samples, so only a small subset of those collected were used for the analysis described below.

\section{Interpretation of bands}

A total of 1207 spines, 66 rays, 35 otoliths, and 216 scale sets were used for age analysis (Table 1). Readers agreed on $86 \%$ of the spine counts and $48 \%$ of the ray counts. Agreement within $1 \mathrm{yr}( \pm 1 \mathrm{yr})$ was reached for $96 \%$ of the spines and $78 \%$ of the rays. After a second reading, 93 spines and 18 rays were discarded either because of poor quality of the section or because agreement could not be reached between readers, leaving 1114 spines and 48 rays for analysis.

Readers examined 35 sectioned otoliths, agreeing on $89 \%$ of otolith ages, and agreeing \pm 1 yr for $97 \%$ (Table 1). After a joint reading, 3 otoliths were discarded either because of disparity between readers or because of poor quality of the sections, leaving 32 otoliths for analysis.

Table 1. Epinephelus itajara. Percent agreement (initial reading) of annuli counts between independent readers for all age structures. $\% \pm 1$ : readers in agreement $\pm 1 \mathrm{yr}_{;} \% \pm 2+$ : readers in agreement $\pm 2 \mathrm{yr}$

\begin{tabular}{|lrccc|}
\hline & $\mathrm{n}$ & $\%$ agreement & $\% \pm 1$ & $\% \pm 2+$ \\
\hline Spines & 1207 & 86 & 10 & 3 \\
Rays & 66 & 48 & 30 & 21 \\
Otoliths & 35 & 89 & 9 & 3 \\
All scales & 149 & 43 & 38 & 19 \\
Dorsal scales & 216 & 38 & 39 & 23 \\
Belly scales & 216 & 35 & 42 & 23 \\
Tail scales & 216 & 34 & 39 & 27 \\
\hline
\end{tabular}

Readers analyzed 216 scale sets in an attempt to determine ages. Within-reader agreement was $16.9 \%$, with only $3.7 \%$ of samples showing unanimous agreement across all 6 readings for each fish. Betweenreader agreement for scales using the mode of the 6 readings $(\mathrm{n}=149)$ was $43 \%$, with $39 \%$ agreeing \pm 1 yr. Reader agreement for dorsal, belly, and tail scales was 38,35 , and $34 \%$, respectively.

\section{Validation of annuli in spines}

Fish ( $\mathrm{n}=152$ ) ranging in size from 186 to $1000 \mathrm{~mm}$ TL $($ mean $=539.3 \mathrm{~mm})$ were injected with OTC. Of all OTC-injected fish $46 \%$ were recaptured. OTC marks were clearly visible (by unaided eye) in spine and ray sections. We observed discernable OTC marks in hard parts from fish that were injected with just $11.6 \mathrm{mg}$ $\mathrm{kg}^{-1}$ of OTC. We also recaptured 3 healthy animals that we considered 'overdosed' (>100 mg OTC kg ${ }^{-1}$ ), including an individual accidentally injected with $426.2 \mathrm{mg} \mathrm{kg}^{-1}$. It is apparent that juvenile goliath grouper can survive higher than advocated doses of OTC.

We recorded spine ages of juvenile goliath grouper that had been recaptured after at least $1 \mathrm{yr}$ at large to determine if age (number of annuli) increased proportionally to time at large. Of the fish analyzed in this manner ( $n=100), 92 \%$ showed the expected growth while at liberty, either through appropriate increases in age $(66 \%)$ or remaining the same age but showing evidence of growth distal of the previous year's annulus mark (26\%) (Fig. 2). Only $8 \%$ showed a decrease in age or ages in excess of time at large.

Edge analysis of sectioned spines and rays (especially those marked with OTC) confirmed that the translucent band was deposited once annually, between August and December (Fig. 3). The percentage of spines and rays with a translucent edge decreased through May and was lowest in June and July. Our small number of otoliths did not include samples from throughout the year, and the samples we did have showed no discernable pattern in edge formation. Therefore, we used data collected by Bullock et al. (1992) showing annulus completion between April and August.

\section{Comparison of ageing structures}

Bullock et al. (1992) confirmed validated ages of goliath grouper using otoliths. Therefore, we compared the utility of non-lethal ageing structures to accepted otolith ages. Otolith annuli counts were regressed against spine, ray, and scale annuli counts (Fig. 4). Spine ages agreed best with otolith ages $(\mathrm{p}<$ 


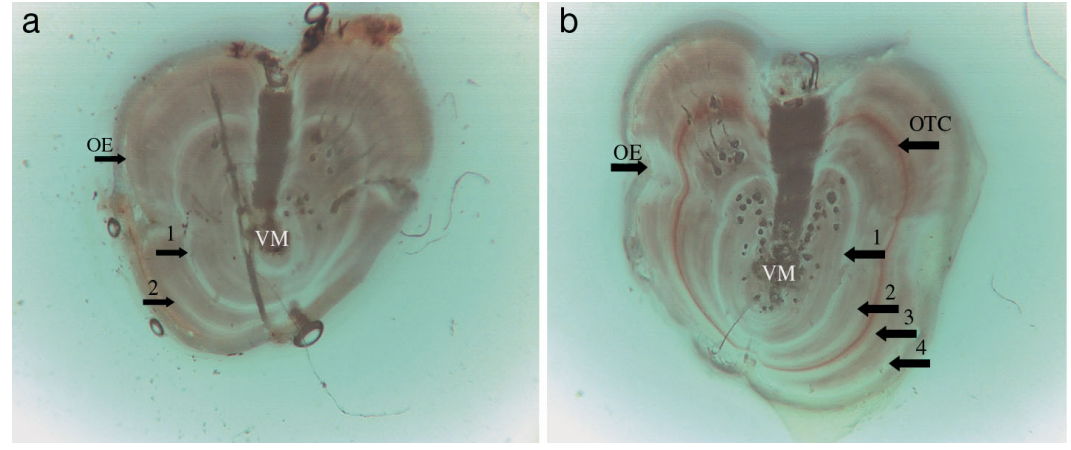

Fig. 2. Epinephelus itajara. A juvenile goliath grouper (ID\#137) captured 4 times over 2 yr: photographs of dorsal spine cross sections taken from (a) date of original capture, October 1999, $365 \mathrm{~mm}$ total length (TL); and (b) from a subsequent capture event in December 2000, $487 \mathrm{~mm}$ TL. This fish was injected with oxytetracycline (OTC) at time of capture in October 1999; note OTC stain visible between 2nd and 3rd annuli in (b). Numbers above arrows refer to annuli. $\mathrm{VM}=$ vascularized matrix, $\mathrm{OE}=$ outer edge were inconsistent, with low reader confidence and agreement and low agreement to corresponding otoliths. We concluded that scales were not a good candidate structure for ageing, as did Welch et al. (1993), LowerreBarbieri et al. (1994), and Ihde \& Chittenden (2002); we thus excluded them from further analysis.

Corrected, biological ages of spines and otoliths agreed within 1 yr $84 \%$ of the time, with $13 \%+1$ yr and $3 \%$ -1 yr. The mean biological age difference between spines and otoliths was 0.09 yr (Fig. 5). A paired $t$-test showed no significant difference $(p<0.001)$ between the biological ages of spine and otolith samples.

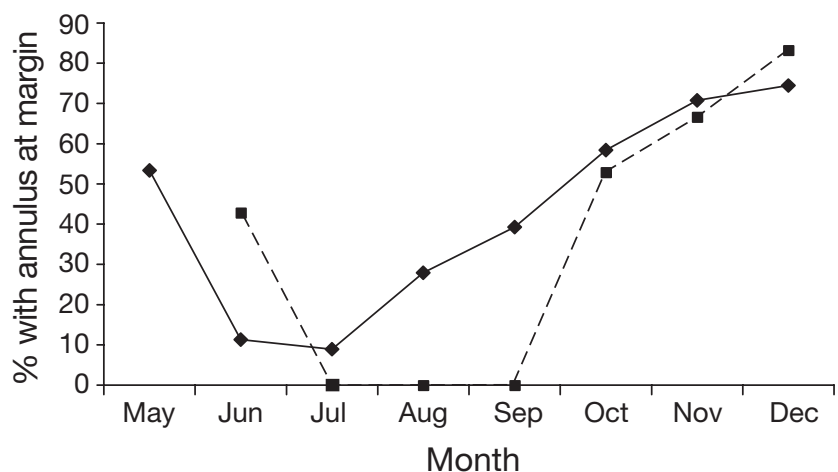

Fig. 3. Epinephelus itajara. Edge analysis of juvenile goliath grouper spine $(\bullet ; \mathrm{n}=1114)$ and ray $\left(\boldsymbol{\square}_{;} \mathrm{n}=48\right)$ sections sampled from 1997 to 2001 from the Ten Thousand Islands area of southwest Florida, USA

$0.001)$, followed by ray ages $(\mathrm{p}<0.05)$, and scales $(\mathrm{p}=$ 0.51). Sixty-three percent of spines agreed with the corresponding otolith $(\mathrm{n}=32), 6 \%$ of spines were $-1 \mathrm{yr}$, and $31 \%$ of spines were $+1 \mathrm{yr}$. Thus, spines tended to agree with otoliths, but at times led to age overestimates of 1 yr.

Eleven ray ages were compared to their corresponding otolith. The remaining rays were discarded either because of disparity between readers or difficulty in reading ray sections. Only $36 \%$ of rays agreed with the corresponding otolith; $36 \%$ of rays were $-1 \mathrm{yr}, 9 \%$ were $-2 \mathrm{yr}$, and $18 \%$ of rays were $+1 \mathrm{yr}$. Overall, the sectioned fin-rays were small and the translucent bands were difficult to read and interpret. Due to the difficulty in reading, low sample size, and low agreement to corresponding otoliths; rays were excluded from further age analysis.

Scales consistently overestimated fish age. Only $21 \%$ of scales agreed with otolith ages; $14 \%$ were $+1 \mathrm{yr}, 29 \%$ were $+2 \mathrm{yr}, 36 \%$ were $\geq+3$ yr. Scale marks

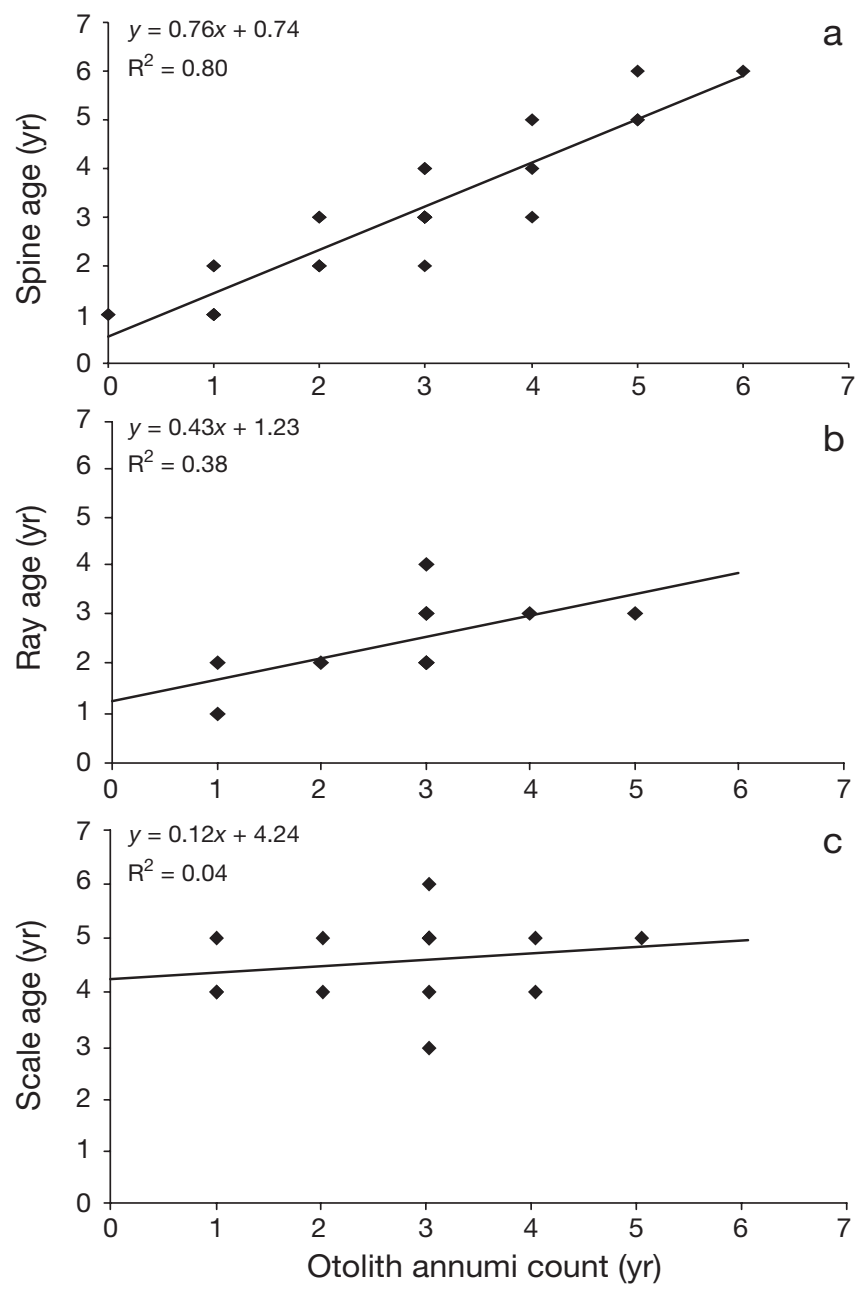

Fig. 4. Epinephelus itajara. Comparison of raw (a) spine $(\mathrm{n}=$ $32)$, (b) ray $(\mathrm{n}=11)$, and (c) scale $(\mathrm{n}=14)$ ages compared to corresponding raw otolith age for juvenile goliath grouper sampled from 1997 to 2001 in the Ten Thousand Islands area of southwest Florida, USA 


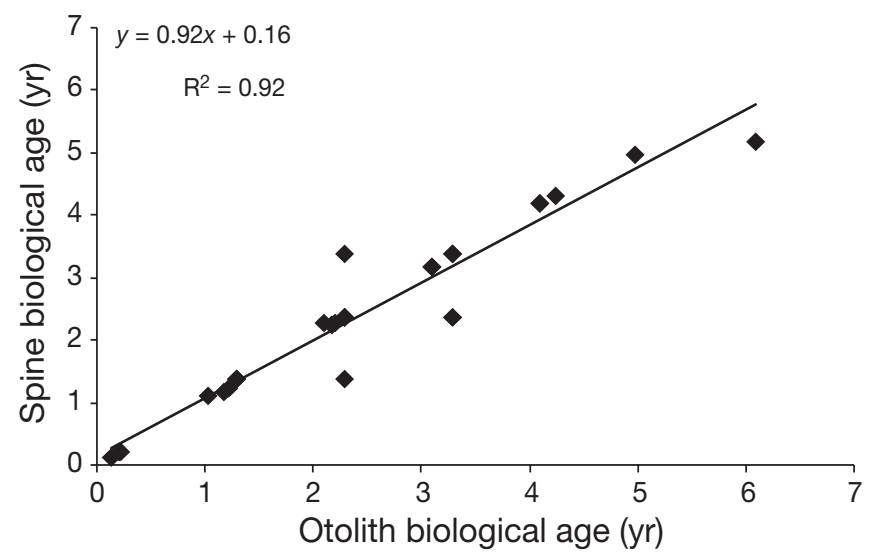

Fig. 5. Epinephelus itajara. Relationship between spine age and corresponding otolith age $(\mathrm{n}=32)$ using biological age calculations for juvenile goliath grouper from the Ten Thousand Islands area of southwest Florida, USA

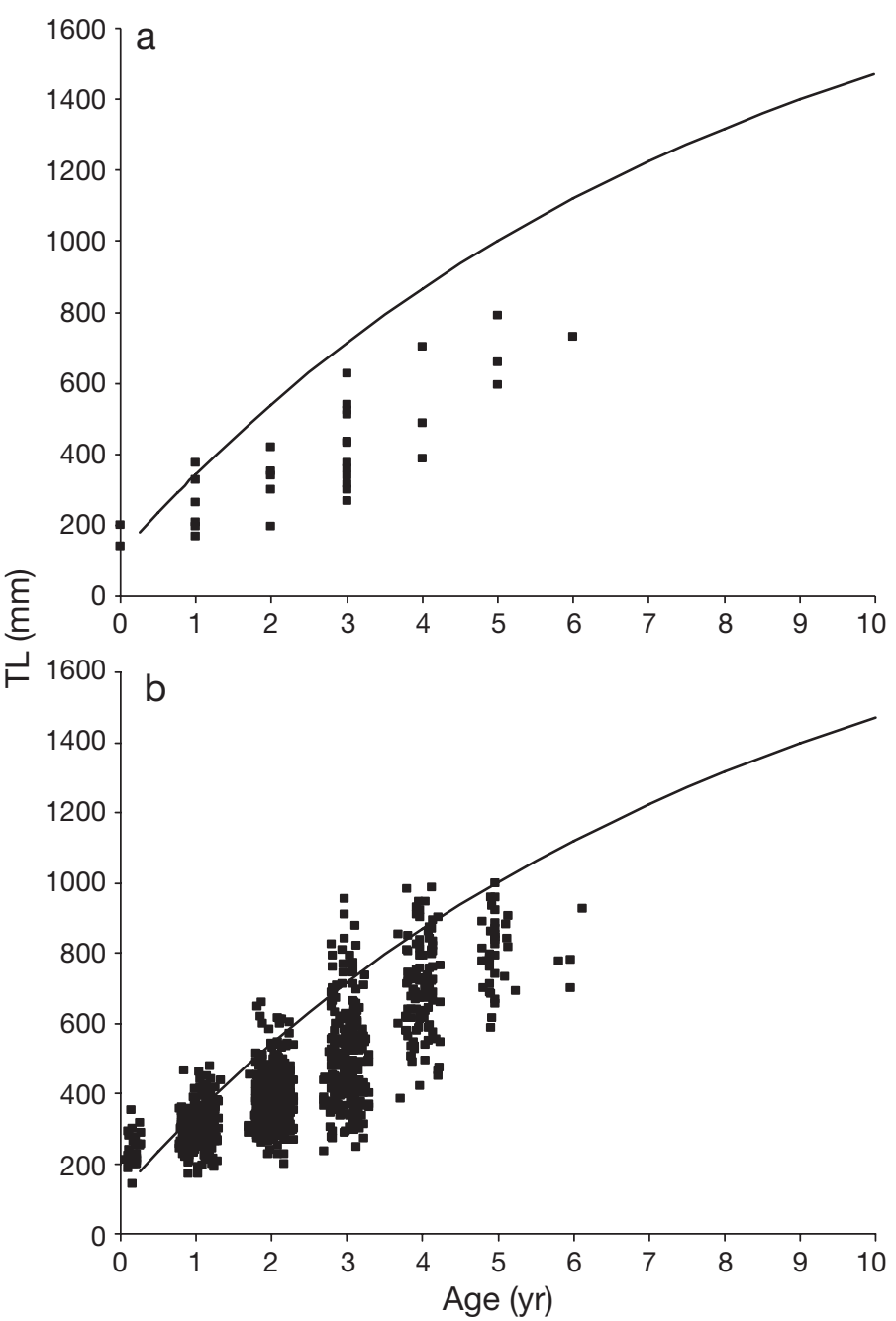

Fig. 6. Epinephelus itajara. (a) Otolith annuli counts $(\mathrm{n}=32)$ and $(b)$ spine biological ages $(\mathrm{n}=1114)$ as compared to Bullock et al. (1992) von Bertalanffy growth parameters. TL: total length
Size at age

Size at age for our study was compared to the von Bertalanffy growth model parameters generated by Bullock et al. (1992) using both raw otolith ages (for side-by-side comparisons) and corrected spine ages in order to compare results from the 2 studies (Fig. 6). In the current study, size at age was generally smaller than the results reported by Bullock et al. (1992), especially at ages greater than 1 yr.

\section{DISCUSSION}

Our research confirmed that dorsal spines are adequate estimators of juvenile goliath grouper age (Age 0 to 6). Spines were simple to collect and process, showed discrete, easy-to-read bands, and their removal did not appear to harm the subject animal, given numerous recaptures over many years. Spinederived ages were validated using 3 methods (OTC, edge analysis, and time at large) and corresponded well to otoliths from the same animal.

Generally, age and growth studies are more successful in younger, faster growing fish (Campana 2001), and this is probably the case in the present study. Ray age correlated positively with otolith and spine ages and showed similar trends in edge analysis; however, reader agreement and correlation to otolith ages was lower with rays than with spines. Ray sections were small and readers tended to have lower confidence in their ability to read them. This tendency has also been shown in other studies (Cass \& Beamish 1983, Ihde \& Chittenden 2002). Scales were also poor predictors of age in the present study and, thus, we rejected using them for age analysis. Scale ages were highly variable both within individual readers and between readers.

Spine annulus formation, in situ growth, OTC validation, and age agreement between spines and otoliths (a previously validated ageing structure for goliath grouper; Bullock et al. 1992) confirmed that our non-lethal age and growth techniques are sound for juvenile goliath grouper. The use of translucent bands as annuli in spines is supported in the literature (Welch et al. 1993, Franks et al. 2000, Ihde \& Chittenden 2002, G. W. Ingram et al. pers. comm.). Fifty mg OTC $\mathrm{kg}^{-1}$ was sufficient to produce a clear, readable mark in spines, rays and otoliths without additional mortality. Injected fish were recaptured up to $2 \mathrm{yr}$ after administration, and all had discernable OTC marks in their spines and rays. This study was able to explore a range of OTC doses in field experiments as opposed to laboratory experiments, as recommended by McFarlane \& Beamish (1987). 
Our recapture data and edge analysis showed that while presumed age rings were indeed formed annually, annulus marks were not formed at the same time of the year in spines and rays as in otoliths. The translucent zone, counted as the annulus mark in spines and rays, was complete in December while the corresponding otoliths opaque zone was complete by August (Bullock et. al. 1992). While this difference is notable, it is not unique (e.g. Lowerre-Barbieri et al. 1994). By assigning biological ages to the fish, we were able to correct for this issue and observe a clearer relationship between hard parts. We echo the concern stated by Lowerre-Barbieri et al. (1994) that differences in hardpart development must be better understood to increase the accuracy of ageing methods and better approximate true biological ages.

For larger or older fish, spines may not be as accurate due to erosion of the spine's core (McFarlane \& King 2001, Ihde \& Chittenden 2002) As fish age, expansion of the central lumen erodes early annuli (caused by increasing amounts of vascularized tissue in the central part of the spine as it changes in structure with age), thereby causing the true age of older fish to be underestimated (Gonzalez-Garces \& Farina-Perez 1983, Franks et al. 2000). Furthermore, slower growth as the animal reaches sexual maturity may compress annuli in spines (Welch et al. 1993). These factors, along with the fact that goliath grouper approaching $6 \mathrm{yr}$ of age and $1 \mathrm{~m}$ in length migrate out of the current study area, inhibited our attempts to obtain samples from fish in this size/age category. A study exploring the use of dorsal fin-rays for ageing adult goliath grouper appears in this Theme Section (Murie et al. 2009). Studies assessing the utility of fin-rays for ageing other groupers such as gag Mycteroperca microlepis and Nassau grouper Epinephelus striatus are in process (D. J. Murie pers. comm.).

Our data showed wide size ranges at age for juvenile goliath grouper, but this is not uncommon for groupers (Manooch \& Mason 1984). Bullock et al. (1992) reported much larger fish at age than our study. Superficially, this difference may be due to differences in time frame of studies (during exploitation versus during recovery), sample locations (central Gulf of Mexico versus southwestern Florida), sample size ( $\mathrm{n}=52$ versus $\mathrm{n}=1114$ ), or ageing method (otoliths versus spines), although our limited otolith data showed the same trend. More likely, these differences are due to gear selectivity of the 2 studies (hook and line versus fish and blue crab traps), since our study would not have captured the largest fish in the environment (Koenig et al. 2007), and migration of larger, faster growing fish from the juvenile habitat and out of our study area. Indeed, anecdotal evidence indicates that smaller and younger size classes of goliath grouper are appearing in offshore environments recently dominated by large adults; this is quite possibly a reflection of increased densities of goliath grouper inshore brought about by the apparent recovery of the species in the estuaries of the Ten Thousand Islands region. Another theory, as stated above (Bullock et al. 1992), is that our fish are depressed in size because of previous fishery exploitation. If this is the case, we would expect to see an increase in size at age in the future as a function of the last $18 \mathrm{yr}$ of recovery (Huntsman et al. 1999).

We believe that our study, in comparison to Bullock et al. (1992), more precisely estimates age of juvenile goliath grouper for fish from 0 to 6 yr of age. Our study succeeded in estimating the age of juvenile goliath grouper using non-lethal methods. Ideally, developing and implementing such ageing methods should be a goal for age and growth studies for protected species, depleted populations and other studies that rely on the survivorship of the study animal. Future investigations must examine age and growth of early post-settlement juveniles and the oldest goliath groupers to better understand the entire life history of this fish.

Acknowledgements. We gratefully acknowledge Anne Marie Eklund, Chris Koenig, Felicia Coleman, Matt Finn, Todd Bevis, and our research team who provided critical assistance in research methodologies and in the field. We thank G. Walter Ingram, Robert Allman, Gary Fitzhugh, Linda LombardiCarlson, Doug DeVries and Shannon Cass-Calay for their expert advice on age and growth and statistical analysis. Special thanks to Joe Serafy for providing critical review of and assistance with this manuscript. Funding for this project was provided by the Curtis and Edith Munson Foundation; NOAA Fisheries, Protected Resources Division; NOAA Fisheries, Essential Fish Habitat; and the Marine Fisheries Initiative (MARFIN).

\section{LITERATURE CITED}

Beamish RJ, McFarlane GA (1983) The forgotten requirement for age validation in fisheries biology. Trans Am Fish Soc 112:735-743

Beamish RJ, McFarlane GA (1985) Annulus development on the second dorsal spine of the spiny dogfish (Squalus acanthias) and its validity for age determination. Can J Fish Aquat Sci 42:1799-1805

Bullock LH, Smith GB (1991) Seabasses (Pisces: Serranidae). Memoirs of the Hourglass Cruises, Vol 8(2). Florida Department of Natural Resources, St. Petersburg, FL

Bullock LH, Murphy MD, Godcharles MF, Mitchell ME (1992) Age, growth, and reproduction of jewfish, Epinephelus itajara, in the eastern Gulf of Mexico. Fish Bull US 90: 243-249

Campana SE (2001) Accuracy, precision and quality control in age determination, including a review of the use and abuse of age validation methods. J Fish Biol 59:197-242

> Cass AJ, Beamish RJ (1983) First evidence of validity of the fin-ray method for age determination for marine fishes. N Am J Fish Manag 3:182-188

Eklund AM, Schull J (2001) A stepwise approach to investigat- 
ing the movement patterns and habitat utilization of goliath grouper, Epinephelus itajara, using conventional tagging, acoustic telemetry and satellite tracking. In: Sibert JR, Nielsen JL (eds), Electronic tagging and tracking in marine fisheries. Kluwer Academic, Dordrecht, p 189-216

Fowler AJ, Short DA (1998) Validation of age determination from otoliths for the King George whiting (Perciformes: Sillaginodes punctata). Mar Biol 130:577-587

Franks JS, Brown-Peterson J, Griggs MS, Garber NM, Warren JR, Laresen KM (2000) Potential of the first dorsal fin spine for estimating the age of wahoo, Acanthocybium solandri, from the northern Gulf of Mexico, with comments on specimens from Bimini, Bahamas. Proc Gulf Caribb Fish Inst 51:428-440

Garcia ER, Potts JC, Rulifson RA, Manooch CS III (2003) Age and growth of yellowtail snapper, Ocyurus chrysurus, from the southeastern United States. Bull Mar Sci 72: 909-921

Gonzalez-Garces A, Farina-Perez AC (1983) Determining age of young albacore, Thunnus Alalunga, using dorsal spines. In: Prince ED, Pulos LM (eds) Proceedings of the international workshop on age determination of oceanic pelagic fishes: tunas, billfishes, and sharks Feb 8-15, 1982. NOAA Tech Rep NMFS 8:117-122

Hudson EJ, Mace GM (1996) Marine fish and the IUCN Red List of threatened animals. Report of the workshop held in collaboration with WWF and IUCN at the Zoological Society of London, April 29-May 1, 1996. Institute of Zoology, Zoological Society of London, London

Huntsman GR, Potts J, Mays RW, Vaughn D (1999) Groupers (Seranidae, Epinephelinae): endangered apex predators of reef communities. In: Musick JA (ed) Life in the slow lane: ecology and conservation of long-lived marine animals. Am Fish Soc Symp 23:217-231

Ihde TF, Chittenden ME Jr (2002) Comparison of calcified structures for aging spotted seatrout. Trans Am Fish Soc 131:634-642

Jearld A Jr (1983) Age determination. In: Nielson LA, Johnson DL (eds) Fisheries techniques. American Fisheries Society, Bethesda, MD, p 301-324

Koenig CC, Coleman FC, Eklund AM, Schull J, Ueland J (2007) Mangroves as essential nursery habitat for goliath grouper (Epinephelus itajara). Bull Mar Sci 80:567-586

Lowerre-Barbieri SK, Chittenden ME Jr, Jones CM (1994) A comparison of a validated otolith method to age weakfish, Cynoscion regalis, with the traditional scale method. US Natl Mar Fish Serv Fish Bull 92:555-568

Editorial responsibility: Kevin Rhodes,

Hilo, Hawaii, USA
Manooch CS III (1987) Age and growth of snapper and groupers. In: Polovina JJ, Ralston S (eds) Tropical snappers and groupers: biology and fisheries management. Westview Press, Boulder, CO, p 329-373

Manooch CS III, Mason DL (1984) Age, growth and mortality of lane snapper from southern Florida. Northeast Gulf Sci $7: 109-115$

McFarlane GA, Beamish RJ (1987) Selection of dosages of oxytetracycline for age validation studies. Can J Fish Aquat Sci 44:905-909

McFarlane GA, King JR (2001) The validity of the fin-ray method of age determination for lingcod (Ophiodon elongatus). Fish Bull US 99:459-464

Murie DJ, Parkyn DC, Koenig CC, Coleman FC, Schull J, FriasTorres S (2009) Evaluation of finrays as a non-lethal ageing method for protected goliath grouper Epinephelus itajara. Endang Species Res 7:213-220

Musick JA, Harbin MM, Berkeley SA, Burgess GH and others (2000) Marine, estuarine, and diadromous fish stocks at risk of extinction in North America (exclusive of Pacific salmonids). Fisheries 25:6-30

Patterson WF III, Cowan JH Jr, Wilson CA, Shipp RL (2001) Age and growth of red snapper, Lutjanus campechanus, from an artificial reef area off Alabama in the northern Gulf of Mexico. Fish Bull (Wash DC) 99:617-627

Sadovy Y, Eklund AM (1999) Synopsis of biological data on the Nassau grouper, Epinephelus striatus (Bloch 1792), and the jewfish, E. itajara (Lichtenstein 1822). US Dept Commerce, NOAA Tech Rep NMFS 146, Tech Rep Fish Bull FAO Fisheries Synopsis 157, US Dept Commerce, Seattle, WA

Secor DH, Dean JM, Laban EH (1992) Otolith removal and preparation for microstructural examination. In: Stevenson DK, Campana SE (eds) Otolith microstructure examination and analysis. Can Spec Publ Fish Aquat Sci 117: $19-57$

Smith KA, Deguara K (2003) Formation and annual periodicity of opaque zones in sagital otoliths of Mugil cephalus (Pisces: Mugilidae). Mar Freshw Res 54:57-67

Welch TJ, Van Den Avyle MJ, Betsill RK, Driebe EM (1993) Precision and relative accuracy of striped bass age estimates from otoliths, scales, and anal fin rays and spines. N Am J Fish Manag 13:616-620

Wilson CA, Nieland DL (2001) Age and growth of red snapper, Lutjanus campechanus, from the northern Gulf of Mexico off Louisiana. Fish Bull (Wash DC) 99:653-664

Submitted: February 15, 2008; Accepted: August 4, 2008 Proofs received from author(s): October 17, 2008 